\title{
Formation of Lipid Oligosaccharides in a Tunicamycin Resistant Mutant of Chinese Hamster Ovary Cells
}

\author{
Atsuko Sehara-Fujisawa, Liria Mónica Masuda* \\ and Kazukiyo ONODERA* \\ Institute for Virus Research, Kyoto University, \\ Sakyo-ku, Kyoto 606, Japan \\ * Department of Agricultural Chemistry, The University of Tokyo, \\ Bunkyo-ku, Tokyo 113, Japan \\ Received March 11, 1985
}

\begin{abstract}
The synthesis of lipid oligosaccharide intermediates of a tunicamycin resistant mutant of Chinese hamster ovary cells was investigated both in vivo and in vitro. It was shown that tunicamycin resistant mutant cells had a significantly lower rate of synthesis of lipid oligosaccharide in vivo and their pool of lipid oligosaccharide was smaller.

The formation of lipid oligosaccharides in vitro using microsomes, however, did not show any defect in the enzymes which were involved in this reaction. The rate of transfer of $\left[{ }^{3} \mathrm{H}\right]$ glucose from UDP- $\left[{ }^{3} \mathrm{H}\right]$ glucose into oligosaccharide of lipid intermediates was the same in wild type and mutant cells while that into glycoproteins was higher in mutant cells than in wild type cells.
\end{abstract}

All high-mannose and complex-asparaginelinked oligosaccharides have in common a core structure of pentasaccharides. ${ }^{2,3)}$ Recent studies have shown that the core structure is synthesized as a lipid-linked precursor, a dolichol-P-P-ClcNAc $\mathrm{Man}_{9} \mathrm{Glc}_{3}$, and this intermediate is transfered en bloc to asparagine residues of nascent polypeptides. ${ }^{4,18)}$ The chemical structure of the lipid oligosaccharides has been conserved from yeast to mammalian cells. $^{5 \sim 7)}$ However, little is known about the enzymes involved in the synthesis of lipid oligosaccharides and the regulation of their synthesis in intact cells except the microsomal localization of the biosynthetic enzymes. ${ }^{8 \sim 12)}$

Tunicamycin resistant $\left(\mathrm{TM}^{\mathrm{R}}\right)$ cells, obtained in this laboratory ${ }^{16)}$ offer a feasible genetic system to examine the regulatory mechanism of glycoprotein biosynthesis. Tunicamycin is an antibiotic which specifically inhibits the first step in the synthesis of lipid oligosaccharides by the following reaction:

\section{Dol-P + UDP-GlcNAc $\rightarrow$ Dol-P-P-GlcNAc + UMP ${ }^{13 \sim 15)}$}

$\mathrm{TM}^{\mathrm{R}}$ cells were assumed to have some defects or modification in the biosynthesis and/or regulation of lipid oligosaccharides. As reported previously, $\mathrm{TM}^{\mathrm{R}}$ cells incorporate less radioactive glucosamine into glycoproteins. ${ }^{1}{ }^{16)}$ In this paper, we show the decreased rate of synthesis of lipid oligosaccharides at the cellular level. However, the decreased rate was not due to the defect in the enzymes which were involved in the synthesis of lipid oligosaccharide.

\section{MATERIALS AND METHODS}

Cells. The wild type CHO cells were obtained from Dr. L. Siminovitch, the Hospital for Sick Children, Toronto, Canada and are auxotrophic for glycine, adenosine, and thymidine and are designated Gat-CHO (B-2). The wild type and mutant cells were routinely maintained as monolayer cultures in $\alpha$-MEM medium supplemented with $10 \%$ fetal calf serum and antibiotics (streptomycin and kanamycin), with passages every three days. The tunica-

Abbreviations: TM, tunicamycin; CHO, Chinese hamster ovary; TM $^{\mathrm{R}}$, tunicamycin resistant; Dol-P, dolicholphosphate; GlcNAc, $N$-acetylglucosamine; Man, mannose; Glc, glucose; UDP, uridine diphosphate; GDP, guanosine diphosphate. 
mycin resistant cell line used in this study was clone $\mathrm{TM}^{\mathrm{R}}$ 205.

Radioactive labeling of cells. Wild type and $\mathrm{TM}^{\mathrm{R}}$ cells were grown to a density of $1 \sim 2 \times 10^{6}$ cells/plate $(60 \mathrm{~mm}$ diameter) and they were exposed to either to $0.1 \mathrm{mCi} / \mathrm{ml}$ of $\left[{ }^{3} \mathrm{H}\right]$ glucosamine or to $0.05 \mathrm{mCi} / \mathrm{ml}$ of $[3 \mathrm{H}]$ mannose in a medium containing $1 \mathrm{~mm}$ glucose. At the times indicated for each experiment, the radioactive medium was removed. Cells were then scraped and extracted with chloroform-methanol-4 mM $\mathrm{MgCl}_{2}$ (3:2:1 by volume) immediately.

Preparation of microsomes. Wild type and mutant cells were grown in spinner culture flasks in a water bath at $37^{\circ} \mathrm{C}$. The concentration of cells was $3 \sim 5 \times 10^{5}$ cells $/ \mathrm{ml}$. Approximately $2 \times 10^{8}$ cells were used in this study for each microsomal preparation.

Cells were harvested by centrifugation at $1000 \times g$ for $10 \mathrm{~min}$. The cell pellet was washed by resuspending in $20 \mathrm{~mm}$ Tris- $\mathrm{HCl}, 0.15 \mathrm{M} \mathrm{NaCl}, \mathrm{pH} 7.4$ and centrifuged at $1000 \times g$ for $10 \mathrm{~min}$ at room temperature. The cell pellet was resuspended in a small volume of Tris-buffered saline $\left(2 \sim 4 \times 10^{7}\right.$ cells $\left./ \mathrm{ml}\right)$ by gentle pipetting and added dropwise to 9 volumes of $20 \mathrm{~mm}$ Tris- $\mathrm{HCl}, \mathrm{pH} 7.4$ at $4^{\circ} \mathrm{C}$ and left to swell for $20 \mathrm{~min}$ at $4^{\circ} \mathrm{C}$. The cells were broken by 20 25 manual strokes by a tight fitting Dounce homogenizer and 0.1 volume of $30 \mathrm{~mm} \mathrm{MgCl}_{2}$ and $0.1 \mathrm{M} \mathrm{NaCl}$ was added. Unbroken cells and nuclei were removed by centrifugation at $1000 \times g$ for $5 \mathrm{~min}$. The resulting supernatant was collected and centrifuged for $1 \mathrm{hr}$ at $4^{\circ} \mathrm{C}$ at $100,000 \times g$. The membranous pellet was resuspended in Tris-buffered saline and the protein content was measured. Finally, the suspension of microsomes was adjusted to a concentration of $10 \mathrm{mg}$ protein $/ \mathrm{ml}$ and used as an enzyme solution.

\section{Measurement of enzyme activity.}

Preincubation: To a sample of $0.03 \mathrm{ml}$ of the membrane suspension, GDP-mannose, $\mathrm{MgCl}_{2}$, and $\mathrm{MnCl}_{2}$ were added in $20 \mathrm{~mm}$ Tris- $\mathrm{HCl}, \mathrm{pH} 7.4$, and $0.05 \mathrm{M} \mathrm{NaCl}$ to a final concentration of $0.72 \mu \mathrm{M}, 0.46 \mathrm{~mm}$, and $0.45 \mathrm{~mm}$, respectively, in a final volume of $0.035 \mathrm{ml}$. This mixture was then incubated at $37^{\circ} \mathrm{C}$ for $20 \mathrm{~min}$.

Assay: The mixture was then diluted with assay components to a final volume of $0.08 \mathrm{ml}$ and the incubation was continued for various times at $37^{\circ} \mathrm{C}$. The final concentrations in the assay mixture were $0.4 \mathrm{mM} \mathrm{MgCl}_{2}$, $0.4 \mathrm{~mm} \mathrm{MnCl}_{2}, 20 \mathrm{~mm}$ Tris- $\mathrm{HCl}$ (pH 7.4), $0.15 \mathrm{M} \mathrm{NaCl}$, and various nucleotide sugars, $75 \mu \mathrm{M}$ UDP- $\left[{ }^{3} \mathrm{H}\right] N$ acetylglucosamine for the assay of $N$-acetylglucosaminyl transferases. $75 \mu \mathrm{M}$ UDP- $N$-acetylglucosamine and $2.0 \mu \mathrm{M}$ GDP- $\left[{ }^{14} \mathrm{C}\right]$ mannose for the assay of mannosyltransferases, and $75 \mu \mathrm{M}$ UDP- $N$-acetylglucosamine, $2.0 \mu \mathrm{M}$ GDP-mannose, and 1.8 $\mu \mathrm{M}$ UDP- $\left[{ }^{3} \mathrm{H}\right]$ glucose for the assay of glucosyltransferases. The mixture contained $0.14 \mathrm{~mm}$ dolichol phosphate when mentioned. The reaction was stopped by the addition of 20 volumes of chloroform-methanol $(2: 1, \mathrm{v} / \mathrm{v})$.

Extraction of lipid oligosaccharides. Lipids were extracted by the method of Hubbard and Robbins. ${ }^{17)}$ The materials which were extracted with chloroformmethanol- $4 \mathrm{~mm} \quad \mathrm{MgCl}_{2} \quad(3: 2: 1$ by volume $)$ and chloroform-methanol-water (10:10:3 by volume) were combined.

Mild acid hydrolysis. The lipid oligosaccharide fractions were pooled and transferred to a screw-cap tube. The solvent was evaporated at $30 \sim 40^{\circ} \mathrm{C}$ under a stream of nitrogen. The residue was resuspended in $1.2 \mathrm{ml}$ of $0.01 \mathrm{~N}$ $\mathrm{HCl}$ in $50 \%$ propanol and the tube was capped. After $20 \mathrm{~min}$ at $100^{\circ} \mathrm{C}$, the tube was cooled and lipid-free oligosaccharides were obtained after partition.

Gel filtration. Bio-Gel P-4 column (200 400 mesh, $1 \times 120 \mathrm{~cm}$, Bio Rad) was used to resolve the oligosaccharides. The elution buffer was $0.1 \mathrm{M}$ Tris- $\mathrm{HCl}(\mathrm{pH} 8.0)$ containing $0.5 \mathrm{~mm}$ sodium azide or $0.1 \mathrm{M}$ ammonium bicarbonate $(\mathrm{pH} 8.0)$. The oligosaccharides migrated in the same position in both solvents. Samples were put on the column in a volume of $200 \mu \mathrm{l}$ and $0.45 \mathrm{ml}$ fractions were collected. Markers for exclusion ( $500 \mu \mathrm{g}$ of bovine serum albumin) and inclusion ( $1000 \mathrm{cpm}$ of $\left[{ }^{3} \mathrm{H}\right]$ mannose) volumes were added in each run. The column was calibrated with oligosaccharide markers kindly provided by Dr. C. Hubbard of M.I.T., Cambridge, Mass., U.S.A.

Chemicals. 1,6- $\left[{ }^{3} \mathrm{H}\right]$ Glucosamine- $\mathrm{HCl}(6.6 \mathrm{Ci} / \mathrm{mmol})$, D2- $\left[{ }^{3} \mathrm{H}\right]$ mannose $(16 \mathrm{Ci} / \mathrm{mmol})$, UDP-D-[6- $\left.{ }^{3} \mathrm{H}\right]$ glucose $(8.6$ $\mathrm{Ci} / \mathrm{mmol})$, UDP-[U- $\left.{ }^{14} \mathrm{C}\right] \mathrm{glucosamine}(60.8 \mathrm{mCi} / \mathrm{mmol})$ were purchased from Amersham. UDP-D-[6- $\left.{ }^{3} \mathrm{H}(\mathrm{N})\right] N$ acetyl-D-glucosamine $\quad(24 \mathrm{Ci} / \mathrm{mmol}), \quad \mathrm{GDP}-\left[\mathrm{U}-{ }^{14} \mathrm{C}\right]$ mannose $(269 \mathrm{mCi} / \mathrm{mmol})$, and $\mathrm{UDP}-\left[\mathrm{U}-{ }^{14} \mathrm{C}\right] N$-acetylD-glucosamine $(306 \mathrm{mCi} / \mathrm{mmol})$ were purchased from New England Nuclear. Dolichol phosphate (Grade 3), $N, N$-diacetylchitobiose, UDP- $N$-acetylglucosamine, and GDP-mannose were purchased from Sigma Chemicals Co.

\section{RESULTS}

Incorporation of $\left[{ }^{3} \mathrm{H}\right]$ mannose and $\left[{ }^{3} \mathrm{H}\right] \mathrm{glu}$ cosamine into lipid oligosaccharides and glycoproteins

To compare the formation of lipid oligosaccharides in $\mathrm{TM}^{\mathrm{R}}$ cells with wild type cells, both were labeled with $\left[{ }^{3} \mathrm{H}\right]$ mannose for $30 \mathrm{~min}$. As was shown in Table I, TM ${ }^{\mathrm{R}}$ cells incorporated less radioactivity. into lipid oligosaccharide than wild type, while incorporation of $\left[{ }^{3} \mathrm{H}\right]$ mannose into glycoproteins in $\mathrm{TM}^{\mathrm{R}}$ cells 
Table I. Distribution of Radioactivity in Cells Labeled With $\left[{ }^{3} \mathrm{H}\right]$ Mannose and $\left[{ }^{3} \mathrm{H}\right]$ Glucosamine

\begin{tabular}{|c|c|c|c|}
\hline \multirow{2}{*}[{}^{3}\mathrm{H}]{} & \multirow{2}{*}{ Cells } & \multicolumn{2}{|c|}{ Lipid } \\
\hline & & Oligosaccharide & Glycoproteins \\
\hline \multirow{2}{*}{ Mannose } & Wild type & 20.8 & 2.32 \\
\hline & $\mathrm{TM}^{\mathrm{R}}$ cells & 2.75 & 2.02 \\
\hline \multirow{2}{*}{ Glucosamine } & Wild type & 1.32 & 5.19 \\
\hline & $\mathrm{TM}^{\mathrm{R}}$ cells & 0.21 & 1.27 \\
\hline
\end{tabular}

Unit: $\times 10^{-1} \mathrm{cpm}$. Values were the average of six culture.

The extraction procedure is described in MATERIALS AND Methods.
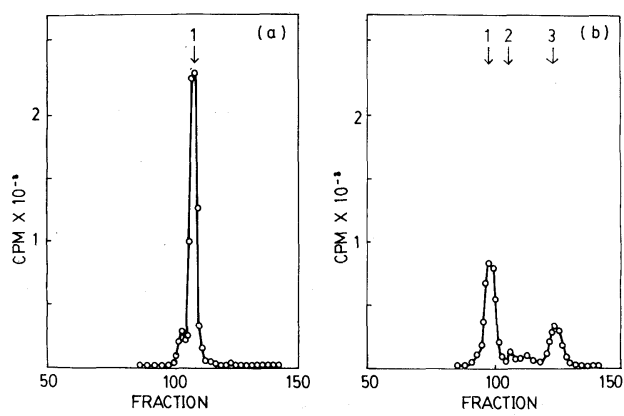

Fig. 1 (a) AND (b). Bio-Gel P-4Chromatogram of Lipid Oligosaccharides Isolated from Wild Type (a) and $\mathrm{TM}^{\mathrm{R}} 205$ (b) Labeled with $\left[{ }^{3} \mathrm{H}\right]$ mannose for $30 \mathrm{~min}$.

Lipid oligosaccharides were extracted, hydrolyzed, and chromatographed as described in MATERIALS AND Methods. The markers from the left are 1) $\left.\mathrm{Glc}_{3} \mathrm{Man}_{9} \mathrm{GlcNAc}_{2}, 2\right) \mathrm{Man}_{5} \mathrm{GlcNAc}_{2}$.

was $80 \sim 90 \%$ of the wild type level. Since the total uptake of $\left[{ }^{3} \mathrm{H}\right]$ mannose into $\mathrm{TM}^{\mathrm{R}}$ cells was similar to that into wild type cells ${ }^{1)}$ and the incorporation of radioactivity into the lipid oligosaccharide fraction reached a plateau within $10 \mathrm{~min}$ in both types of cells, the data were assumed to represent the decreased amount of lipid oligosaccharide in $\mathrm{TM}^{\mathrm{R}}$ cells. On the other hand, when the cells were labeled with $\left[{ }^{3} \mathrm{H}\right]$ glucosamine, $\mathrm{TM}^{\mathrm{R}}$ cells incorporated less radioactivity not only into lipid oligosaccharide but also into the glycoprotein fraction (Table I).

Analysis of sugar moieties of lipid oligosaccharides on Bio-Gel P-4 column

Lipid oligosaccharides extracted from $\left[{ }^{3} \mathrm{H}\right]$ mannose labeled cells were hydrolyzed with mild acid and the released oligosaccharide moieties were fractionated on a BioGel P-4 column. The chromatographic profile of wild type cells is shown in Fig. 1a. Most of the radioactivity was found in a peak migrating in the position of the standard marker $\mathrm{Glc}_{3} \mathrm{Man}_{9} \mathrm{GlcNAc}_{2}$ with a $K d$ of $0.280(K d$ value $=(V e-V o) /(V i-V o), V e$; elution volume, $V o$; void volume, $V i$; internal volume). A minor peak with a $K d$ of 0.449 was also detected. By its $K d$ value, this compound is $\mathrm{Man}_{5} \mathrm{GlcNAc}_{2}$.

The chromatographic pattern of the sample obtained from the mutant is shown in Fig. 1 b. The peaks are $\mathrm{Glc}_{3} \mathrm{Man}_{9} \mathrm{GlcNAc}_{2} \quad(K d$; $0.280), \quad \operatorname{Man}_{8} \mathrm{GlcNAc}_{2}(K d ; \quad 0.368)$, and $\mathrm{Man}_{5} \mathrm{GlcNAc}_{2}(K d ; 0.449)$. These oligosaccharides were further characterized by endo- $\beta$ $\mathrm{N}$-acetylglucosaminidase $\mathrm{H}$ and $\alpha$-mannosidase treatment, indicating the structure of lipid oligosaccharides of $\mathrm{TM}^{\mathrm{R}}$ cells is identical to that of wild type cells (data not shown).

Since GlcNAc-lipid and (GlcNAc) $)_{2}$-lipid could not be detected as lipid oligosaccharide intermediates in $\left[{ }^{3} \mathrm{H}\right]$ mannose labeled cells, both types of cells were labeled with $\left[{ }^{3} \mathrm{H}\right]$ glucosamine and the sugar moieties of lipid intermediates were analyzed. The pool size of GlcNAc-lipid, (GlcNAc),-lipid and the other intermediates shorter than $(\mathrm{Man})_{5}(\mathrm{GlcNAc})_{2}$-lipid seemed to be so small that most of the counts was incorporated rapidly into the longer lipid oligosaccharides 


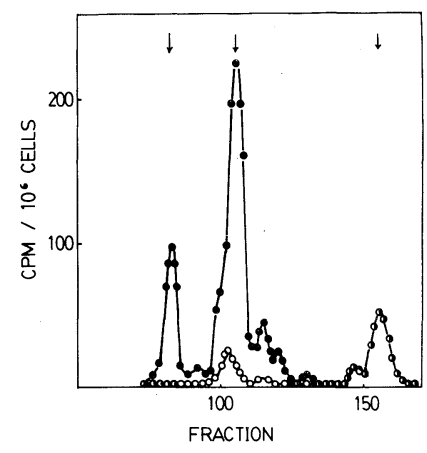

FIG. 2. (a). Bio-Gel P-4 Chromatogram of lipid Oligosaccharides from Wild Type and $\mathrm{TM}^{\mathrm{R}}$ Cells Labeled with $\left[{ }^{3} \mathrm{H}\right]$ Glucosamine for $3 \mathrm{~min}$.

Extracted oligosaccharides were hydrolyzed and chromatographed on Bio-Gel P-4 (minus 400 mesh). The markers from the left are $\mathrm{Glc}_{3} \mathrm{Man}_{9} \mathrm{GlcNAc}_{2}, \mathrm{Man}_{5} \mathrm{GlcNAc}_{2}$ and Man. Wild type (- - ), TM$^{\mathrm{R}} 205$ (-O-).

in both types of cells. Most of the counts was recovered in $(\mathrm{Man})_{5}(\mathrm{GlcNAc})_{2}$-lipid within $3 \mathrm{~min}$ both in wild type and $\mathrm{TM}^{\mathrm{R}}$ cells (Fig. 2a). In wild type cells, a minor peak in the position of $\mathrm{Glc}_{3} \mathrm{Man}_{9} \mathrm{GlcNAc}_{2}$ was also detected. In the mutant cells the peak of this compound was scarcely detectable. There was no great difference in the amount of other shorter intermediates.

\section{Pulse chase experiment on the formation of lipid oligosaccharides}

To measure the turnover of the lipid oligosaccharides, a pulse chase experiment was done. Both types of cells were labeled for $3 \mathrm{~min}$ with $\left[{ }^{3} \mathrm{H}\right]$ glucosamine and cells were washed and reincubated with MEM medium supplemented with $10 \%$ fetal calf serum. Cells were harvested several times and lipid oligosaccharides which were extractable with chloroform-methanol-water $(10: 10: 3$ by volume) were prepared. As shown in Fig. 2b, incorporation of radioactivity into lipid oligosaccharides proceeded for $10 \mathrm{~min}$ in wild type cells, while in $\mathrm{TM}^{\mathrm{R}}$ cells, the formation reached a plateau after $3 \mathrm{~min}$.

The results of the pulse chase experiment demonstrate that in mutant cells the pool size of lipid oligosaccharide intermediates was smaller and the formation of $(\mathrm{Glc})_{3}(\mathrm{Man})_{9^{-}}$

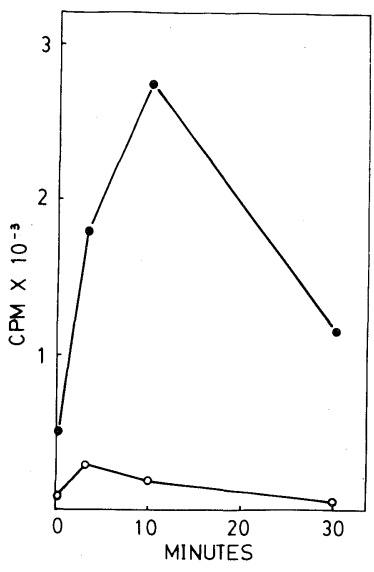

Fig. 2 (b). Pulse Chase Experiment on the Formation of $\left[{ }^{3} \mathrm{H}\right]$ Glucosamine Labeled Lipid Oligosaccharides.

After both types of cells were labeled with $\left[{ }^{3} \mathrm{H}\right]$ glucosamine for $3 \mathrm{~min}$, they were washed and reincubated with the medium without $\left[{ }^{3} \mathrm{H}\right]$ glucosamine for 0 , 3, 10 and $30 \mathrm{~min}$. Wild type (--), TM 205 (-○一).

$(\mathrm{GlcNAc})_{2}$-lipid was reduced dramatically compared to wild type cells.

Formation of glucosamine containing lipid oligosaccharides in vitro

One possible explanation for the significant reduction of lipid oligosaccharide synthesis in $\mathrm{TM}^{\mathrm{R}}$ cells would be some defect in the enzymes involved in the synthesis. It has been reported that the microsomal fraction contains the enzyme activity for lipid oligosaccharide synthesis and glycosylation of proteins. Since tunicamycin inhibits the first step of the synthesis of lipid oligosaccharides, this reaction was compared using the microsomal fractions from both types of cells.

The profile of sugar moieties of lipid oligosaccharide obtained in $2 \mathrm{~min}$ of incubation with the microsomal fraction, UDP- $N$-acetylglucosamine and dolichol phosphate is shown in Fig. 3. Both types of cells showed similar profiles. Typical Michaelis-Menten kinetics with $V_{\max }$ values of 9.2 and $8.2 \times 10^{2} \mathrm{cpm} / \mathrm{mg}$ protein $/ 10 \mathrm{~min}$ for wild type and mutant cells, respectively, was obtained. From their Lineweaver-Burk plots, the $K m$ values of $33.3 \mu \mathrm{M}$ for wild type and $31.3 \mu \mathrm{M}$ for mutant cells were calculated (data not shown). The 

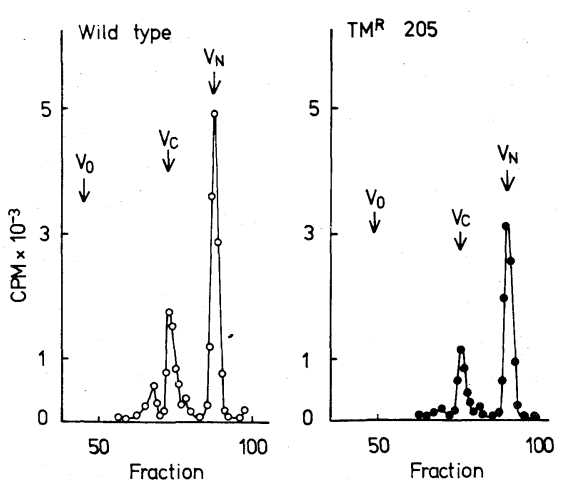

FIG. 3. Bio-Gel P-2 Chromatogram of Glucosamine Containing Lipid Oligosaccharide Synthesized in vitro.

Microsomal fractions from wild type (-O-) and $\mathrm{TM}^{\mathrm{R}} 205(--)$ cells were incubated with UDP- $\left[{ }^{3} \mathrm{H}\right] \mathrm{N}$ acetylglucosamine for $5 \mathrm{~min}$ in the presence of dolichol phosphate. Lipid oligosaccharides were extracted, hydrolyzed, and chromatographed. Markers from the left are $V o$ (bovine serum albumin), $V c$ ( $N, N$-diacetylchitobiose) and $V n$ ( $N$-acetylglucosamine).

data implied that transferases with the same properties were working in both types of membranes.

To follow the conversion of GlcNAc-lipid and (GlcNAc) $)_{2}$-lipid into lipid oligosaccharide a pulse chase experiment was done. The microsomal fraction was incubated with UDP- $\left[{ }^{3} \mathrm{H}\right]-$ acetylglucosamine for $5 \mathrm{~min}$, and then a large excess of UDP- $N$-acetylglucosamine and GDP-mannose was added to the mixture. In a 5-min pulse, two peaks corresponding to $\mathrm{N}$ acetylglucosamine and $N, N$-diacetylchitobiose were observed in both types of cells. After a 10 -min chase, these precursors were further converted into oligosaccharide, $\operatorname{Man}_{1 \sim 7}$ GlcNAc $_{2}$ (data not shown). The membranes of mutant cells synthesized these compounds at a similar rate to the membranes of wild type cells. The result indicates that no significant difference in the process of conversion of GlcNAc-lipid and (GlcNAc) $)_{2}$-lipid into ligosaccharides up to (Man $)_{6 \sim 7}$ $(\mathrm{GlcNAc})_{2}$-lipid exists between membranes of wild type and mutant cells. Formation of mannose-containing oligosaccharide in vitro was also compared between wild type and the mutant cells. The microsomal fraction was incubated with UDP- $N$-acetyl- glucosamine and GDP-mannose as was described in Materials and Methods. No great difference was observed in the amount of the incorporation into lipid oligosaccharide and the profile of gel filtration. In addition, the rate of incorporation of mannose into protein by membranes was the same for both types (data not shown).

\section{Formation of glucose-containing lipid oligo- saccharides}

The incorporation of $\left[{ }^{3} \mathrm{H}\right]$ glucose from UDP- $\left[{ }^{3} \mathrm{H}\right]$ glucose into the lipid fraction, lipid oligosaccharide, and protein was examined. The result is shown in Fig. 4. Incorporation of $\left[{ }^{3} \mathrm{H}\right]$ glucose into lipid and lipid oligosaccharides was the same in both types of membranes. In contrast, an increased rate of glycosylation of proteins by membranes of the mutant cells was observed. The oligosaccharide released from lipid oligosaccharide by mild acid hydrolysis was $\mathrm{Glc}_{3} \mathrm{Man}_{9} \mathrm{GlcNAc}_{2}$. This implies that the final product in formation of lipid oligosaccharides was produced in the reaction and the transfer of oligosaccharide into protein proceeded.

\section{DISCUSSION}

It was found that $T M^{\mathrm{R}}$ cells had a significantly decreased pool of lipid oligosaccharide. Although some defect in the synthesis of lipid oligosaccharide or their precursors affects the pool size of lipid oligosaccharide in the mutant, they can still provide sufficient sugar moieties for glycoprotein synthesis. In $T M^{R}$ cells the rate of glycosylation seems not to be controlled by the size of the lipid oligosaccharide pool but is dependent on some other factors, probably on the rate of synthesis of acceptor proteins themselves. The observed increase in the rate of transfer of oligosaccharide into acceptor polypeptide (Fig. 4) may be the secondary effect of that.

We did not find out why lipid oligosaccharide synthesis is decreased in the mutant cells since there was no reduction in the enzymatic activity involved in the synthesis of lipid 


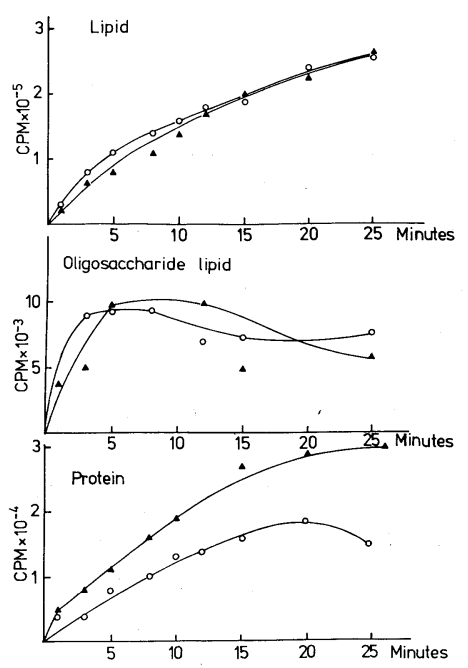

FIG. 4. Kinetics of Incorporation of $\left[{ }^{3} \mathrm{H}\right]$ Glucose from UDP- $\left[{ }^{3} \mathrm{H}\right]$ Glucose into Various Fractions.

The incubation was done as described in MATERIALS AND Methods. The reaction mixture contained dolichol phosphate. Wild type (-O-) and $\mathrm{TM}^{\mathrm{R}}$ cells $(-\mathbf{\Delta}-)$.

oligosaccharide. In addition, the first reaction which is a target of tunicamycin remained sensitive to tunicamycin. ${ }^{21)}$ Since a preliminary experiment suggested that the rate of synthesis of UDP- $N$-acetylglucosamine was the same in the mutant cells as in wild type cells (unpublished), we considered that the lesion of TM $205^{\mathrm{R}}$ is in a step after the synthesis of UDP- $N$-acetylglucosamine.

The localization and translocation of lipid oligosaccharide in the endoplasmic reticulum have been studied. ${ }^{19,20)}$ Hanover and Lennarz showed that (GlcNAc) $)_{2}$-lipid is in the lumenal phase of the endoplasmic reticulum ${ }^{19}$ ) and they suggested the existence of pool of UDP- $N$ acetylglucosamine or its precursor in the lumenal phase of endoplasmic reticulum. ${ }^{21)}$ If the same mechanism is operating in $\mathrm{CHO}$ cells, one possibility is that $\mathrm{TM}^{\mathrm{R}}$ cells has the lesion in this system, for example, in the transport of UDP- $N$-acetylglucosamine across the endoplasmic reticulum. Such a lesion may cause the reduction in lipid oligosaccharide without any change in the enzymes involved in their synthesis and may explain the resistance of the mutant to tunicamycin because it is an ana- logue of UDP- $N$-acetylglucosamine and may be translocated using the same transport system.

As is shown in Table I, the incorporation of $\left[{ }^{3} \mathrm{H}\right]$ glucosamine into glycoproteins in $\mathrm{TM}^{\mathrm{R}}$ cells was approximately one fourth of wild type incorporation. The result is different from the data on $\left[{ }^{3} \mathrm{H}\right]$ mannose in which the incorporation of the radioactivity into glycoproteins in $\mathrm{TM}^{\mathrm{R}}$ cells was $80 \sim 90 \%$ of wild type level. The discrepancy must be due to the difference of the pathways through which both compounds are incorporated into glycoproteins. $\left[{ }^{3} \mathrm{H}\right]$ Mannose is incorporated into glycoproteins via a lipid oligosaccharide intermediate. $\left[{ }^{3} \mathrm{H}\right]$ Glucosamine is incorporated into glycoproteins not only from lipid oligosaccharide but also directly from UDP- $N$ acetylglucosamine by terminal transferases. It is possible that the observed decrease in $\left[{ }^{3} \mathrm{H}\right]$ glucosamine in corporation into glycoproteins is the decrease in the terminal transfer of $\left[{ }^{3} \mathrm{H}\right]$ glucosamine.

\section{REFERENCES}

1) A. Sehara, T. Sudo and K. Onodera, Agric. Biol. Chem., 45, 1825 (1981).

2) C. J. Waechter and W. J. Lennarz, Ann. Rev. Biochem., 45, 95 (1976).

3) R. Kornfeld and S. Kornfeld, Ann. Rev. Biochem., 45, 217 (1976).

4) S. C. Hubbard and R. J. Ivatt, Ann. Rev. Biochem., 50, 555 (1981).

5) R. B. Trimble, J. C. Byrd and F. Maley, J. Biol. Chem., 255, 11892 (1980).

6) I. K. Vijay, G. H. Perdew and D. E. Lewis, J. Biol. Chem., 255, 11210 (1980).

7) J. A. Henner, M. J. Kessler and O. P. Bahl, J. Biol. Chem., 256, 5997 (1981).

8) C. L. Villemez and P. L. Carlo, J. Biol. Chem., 255, 8174 (1980).

9) E. L. Kean, J. Biol. Chem., 255, 1921 (1980).

10) J. P. Spencer and A. D. Elbein, Proc. Natl. Acad. Sci. U.S.A., 77, 2524 (1980).

11) J. W. Jensen and J. S. Schulzbach, J. Biol. Chem., 256, 12899 (1981).

12) R. K. Keller, D. Y. Boon and F. C. Crum, Biochemistry, 18, 3946 (1979).

13) A. Takatsuki, K. Arima and G. Tamura, J. Antibiot., 24, 215 (1971).

14) A. Takatsuki, K. Kawamura, M. Okina, Y. Kodama, T. Ito and G. Tamura, Agric. Biol. Chem., 
41, 2307 (1977).

15) I. S. Tkacz and J. O. Lampen, Biochem. Biophys. Res. Commun., 65, 248 (1975).

16) T. Sudo and K. Onodera, J. Cell Physiol., 101, 149 (1979).

17) S. C. Hubbard and R. W. Robbins, J. Biol. Chem., 254, 4568 (1979).
18) E. Li, I. Tabas and S. Kornfeld, J. Biol. Chem., 252, 7762 (1978).

19) J. A. Hanover and W. J. Lennarz, J. Biol. Chem., 257, 2787 (1982).

20) M. D. Snider and O. C. Rogers, Cell., 36, 753 (1984).

21) K. Onodera, "Tunicamycin," ed. by G. Tamura, Japan Scientific Societies Press, 1982, p. 147. 